\title{
Pertimbangan Halal Thayyib Pada Wisata Non Halal Di Madura
}

\author{
Harisah, ${ }^{1}$ R Suhaimi, ${ }^{2}$ Syarifah Gustiawati Mukri ${ }^{3}$ \\ Institut Agama Islam Negeri Madura \\ Universitas Islam Negeri Sunan Kalijaga Yogyakarta \\ Universitas Ibn Khaldun UIKA Bogor \\ doi https://doi.org/10.32507/mizan.v4i2.818
}

\begin{abstract}
This article presents the response of the Madurese community to tourism that has economic potential. However, it is considered to have no lawful means even thayyiban. The paradigm was born because the religious nature of the Madurese people is still very strong, especially for people who are still traditional. Because this study presents the responses and actions of the Madurese community, the testing method uses qualitative interview and observation techniques related to tourism which was damaged due to demonstrations by the Madurese community. This study found that the Madurese community is very aggressive towards tourism which is considered to cause immorality, uses promotions that are considered to violate the Islamic order, and destroys local Madurese culture, especially the world order of the pesantren. This is done with the consideration that every economic source must be in line with the concepts of halal and thayyib.
\end{abstract}

Keyword: Halal Thayyib, Tourism, Madura

\begin{abstract}
Abstrak
Artikel ini menyajikan respon masyarakat Madura terhadap wisata yang memiliki potensi ekonomi. Namun, dianggap tidak memiliki cara yang halal bahkan thayyiban. Paradigma terlahir karena sifat keber-agamaan orang Madura masih sangat kental terutama bagi masyarakat yang masih tradisional. Oleh karena kajian ini menyajikan respond dan tindakan masyarakat Madura, maka metode pengujian menggunakan kualitatif dengan teknik wawancara dan observasi terkait wisata yang rusak karena didemo oleh masyarakat Madura. Penelitian ini menemukan, bahwa masyarakat Madura sangat agresif terhadap wisata yang dianggap menimbulkan kemaksiatan, menggunakan promosi yang dianggap melanggar tatanan syariah, serta merusak budaya lokal Madura terutama tatanan dunia pesantren. Hal ini dilakukan dengan pertimbangan bahwa setiap sumber ekonomi harus sejalan dengan konsep halal dan thayyib.
\end{abstract}

Keyword: Halal Thayyib, Wisata, Madura

\footnotetext{
* Naskah diterima tanggal: 18 September 2020, direvisi: 12 Oktober 2020, disetujui untuk terbit: 10 Desember 2020.

${ }^{1}$ Harisah adalah dosen Institut Agama Islam Negeri Madura Email: harisah@iainmadura.ac.id)

2 R Suhaimi adalah dosen Universitas Islam Negeri Sunan Kalijaga Yogyakarta, Email: rsuhaimi09@gmail.com

3 Syarifah Gustiawati Mukri adalah dosen Universitas Ibn Khaldun UIKA Bogor Email: syarifah@fai.uika-bogor.ac.id.
} 


\section{A. PENDAHULUAN}

Halalan berarti diperbolehkan setiap perbuatan manusia baik terhadap Allah ataupun terhadap manusia dengan cara yang sah menurut hukum Islam, beda halnya dengan benda atau uang yang diperoleh dengan cara misalnya mencuri, menyuap, menipu dan menggelapkan barang, meskipun benda tersebut layak dan halal namun sifatnya adalah haram. ${ }^{4}$ segala bentuk transaksi yang diperbolehkan menurut syariah maka dikatakan bahwa transaksi tersebut halal. Pada era modern ini penting untuk memastikan kehalalan dari suatu transaksi selain untuk menjaga kegiatan kita dari yang tidak halal, hal ini juga menjadi peluang bagi pelaku usaha untuk mendapatkan kesempatan usaha yang sukses. Sesuai dengan pernyataan I Zulfa persepsi masyarakat terhadap lebel halal sudah menjadi kesan yang telah dianalisa, di interpretasi kemudian dievaluasi oleh individu yang menghasilkan sebuah makna bahwa setiap yang berlebel halal itu telah terjamin kehalalannya dan diperbolehkan dalam Islam. ${ }^{5}$, masyarakat sudah mulai mempertimbangkan usaha yang halal untuk mendapatkan manfaat yang lebih.

Konsep halalan tayyiban juga memberikan nilai positif bagi para pelaku usaha yang menerapkannya, akan memberikan keberkahan serta profit. Namun, bagi pelaku usaha muslim nilai keberkahan menurut syariah menjadi tujuan utama. Hal ini sesuai dengan pernyataan A. H. yusuf, S Abdul Shukron, dan U Ahmad Bustamam keuntungan dalam bisnis hanyalah insidental dalam pemenuhan fardhu kifayah untuk mensejahterakan masyarakat, namun dalam Islam kesuksesan tidak hanya diukur dari hasil akhirnya, tetapi juga sarana dan cara untuk mencapainya. ${ }^{6}$ Produsen memandang bisnis sebagai kegiatan yang tidak hanya mengejar keuntungan materi saja, kesediaan mereka untuk mengintervensi keuntungan materi dengan nilai-nilai sosial dan spiritual sebagai landasan utama dari etos bisnis, kegiatan ini untuk mendapatkan falah (kebahagiaan) di dunia dan akhirat. Visi spiritual bisa lahir dari berbagai bentuk antara lain; kesadaran pelaku bisnis, melakukan tazkiyatun nufus, dan nama produk dengan nama-nama yang ada dalam Islam. Visi ini termotivasi dari keinginan para pelaku bisnis untuk memiliki banyak utilitas seperti membantu orang lain, menyumbang kegiatan sosial, menghindari pengangguran, mendapatkan keuntungan materi, memiliki rasa sosial dan spiritual. ${ }^{7}$

Dalam Islam bisnis merupakan cara terbaik untuk mendapatkan harta sehingga penting menerapkan etika dalam bisnis, penerapan ini merupakan bentuk kesadaran dari pelaku bisnis ketika berhadapan dengan hal baik dan buruk, yang halal dan haram. Maka dengan demikian, segala kegiatan untuk mencari nafkah ini harus dilakukan

\footnotetext{
${ }^{4}$ Hervina Hervina, “Trend Halal Food Di Kalimantan Timur,” FENOMENA 9, no. 2 (2017): 184.

${ }^{5}$ Indana Zulfa, "Pengaruh Persepsi Label Halal Terhadap Minat Beli Dan Keputusan Pembelian Pada Produk Wardah Cosmetic: Studi Pada Mahasiswi Fakultas Ekonomi UIN Maulana Malik Ibrahim Malang Angkatan 2014" (PhD Thesis, Universitas Islam Negeri Maulana Malik Ibrahim, 2017), 108.

${ }^{6}$ Asnidar Hanim Yusuf, S. Abdul Shukor, and U. Ahmad Bustamam, "Halal Certification vs Business Growth of Food Industry in Malaysia," Journal of Economics, Business and Management 4, no. 3 (2016): 250 .

${ }^{7}$ Muhammad M. Said and Kaviyarasu Elangkovan, "Halal Label and the Ethics of Business: An Analytical View from Producers," Australian Journal of Basic and Applied Sciences 7, no. 6 (2013): 16-18.
} 
dengan cara yang sangat baik dengan tidak melakukan penipuan, riba, kecurangan dan tindakan kezaliman lainnya, usaha dalam Islam juga bisa dilakukan kerja sama. Setiap harta yang didapatkan dari jalan yang dilarang dari syariah maka akan disebut sebagai harta haram, sehingga urgen manusia yang hidup di masa modern untuk bisa memahami harta haram, karena pada abad modern dituntut untuk mengumpulkan harta sebanyak-banyaknya agar bisa hidup layak dan tenang menghadapi masa depan. ${ }^{8}$. Pertimbangan halal ini juga menjadi fokus utama bagi masyarakat Madura, dengan nuansa masyarakat agamis. Maka, keberadaan bisnis yang non halal menjadi sorotan masyarakat untuk dibina dan diarahkan menjadi bisnis yang halal, seperti keberadaan wisata bukit Bintang yang menjadi salah satu wisata yang dirusak oleh masyarakat Madura karena dianggap menjadi ladang maksiat serta merusak citra lokal pesantren bernuansa Islami.

\section{B. METODE PENELITIAN}

Metode penelitian menggunakan kualitatif dengan teknik wawancara dan observasi terkait wisata yang rusak karena didemo oleh masyarakat Madura terkait respon masyarakat Madura terhadap wisata yang memiliki potensi ekonomi. Namun, dianggap tidak memiliki cara yang halal bahkan thayyiban.

\section{ANALISIS DAN PEMBAHASAN}

\section{Wisata Halal dalam Bisnis Islam}

Menurut kamus besar bahasa Indonesia, pengertian wisata adalah bepergian secara bersama-sama dengan tujuan untuk bersenang-senang, menambah pengetahuan dan lain-lain. ${ }^{9}$ Adapun dalam Bahasa Arab pariwisata disebut rihlah, istilah pariwisata berasal dari bahasa sansekerta yang terdiri dari suku kata (Pari) yang berarti banyak, berkali-kali, berputar-putar, berkeliling, atau bersama, dan wisata artinya bepergian yang dilakukan dari satu tempat ketempat lain, dengan tujuan bermacam-macam, seperti rekreasi atau untuk melihat-lihat mencari dan menyaksikan sesuatu yang indah.

Pariwisata menjadi perbincangan yang sangat vital di negara Indonesia, karena mengingat pertumbuhan ekonomi di Indonesia banyak didukung oleh bisnis pariwisata, karena melihat secara geografis negara Indonesia adalah Negara yang banyak menyimpan tempat-tempat yang penuh dengan sejarah dan tempat-tempat yang indah seperti Pantai, Gunung, Candi Borobudur, Candi Prambanan dan lain sebagainya. Maka dengan adanya tempat-tempat tersebut banyak mengundang para wisatawan baik dari luar negeri maupun dalam negeri untuk mengunjungi tempattempat yang indah menurut pandangan mereka masing-masing.

\footnotetext{
${ }^{8}$ Erwandi Tarmizi, Harta Haram Muamalat Kontemporer, 21st ed. (P.T Berkat Mulia Insani, 2019), 21.

9 “Pengertian Wisata Secara Umum Aneka Tempat Wisata," Desember 2020, Https://anekatempatwisata.com/pengertian-wisata-secara-umum/.
} 
Dengan demikian, adanya pengunjung dari luar Negara ini menjadi faktor penyebab dari pertumbuhan ekonomi yang ada di Indonesia, dalam kajian ekonomi nasional, pariwisata menjadi sektor terbesar dalam pertumbuhan ekonomi karena kontribusi terhadap devisa Negara terbesar kedua setelah industri kelapa sawit yang mencapai USD 15.965 Miliar pada tahun 2016, sedangkan pariwisata menduduki nomor urut kedua mencapai USD 13.568 miliar pada tahun 2016, sedangkan pada tahun 2015 sektor pariwisata berada pada posisi keempat yang memberikan kontribusi terhadap devisa dengan mencapai USD 12.225 Miliar dibawah minyak dan gas USD 18,574 Miliar, kelapa sawit USD 16.427 Miliar batu bara USD 14. 717 Miliar. ${ }^{10}$

Hal ini menjadi sektor unggulan karena beberapa hal, yaitu jumlah destinasi dan investasi pariwisata yang meningkat menjadikannya faktor dalam menciptakan lapangan pekerjaan, insfrastruktur, pengembangan usaha, hingga pendapatan dari ekspor, Indonesia memproyeksikan pada tahun 2019-2020 sektor ini dapat meningkatkan produk domestik bruto sebesar 15 persen, dengan kunjungan 20 juta wisatawan mancanegara, 275 juta perjalanan yang dilakukan wisatawan nusantara dan diharapkan mampu menyerap tenaga kerja hingga 13 juta.

Dalam mewujudkan sasaran pembangunan tersebut, dilakukan berbagai upaya pembangunan pariwisata, sektor ini memiliki perkembangan dalam segmentasi pembangunan ekonomi dan menjadi trend didunia internasional, adapun yang paling populer wisata dunia ditengah-tengah informasi yang sangat luas baik diluar negeri maupun dalam negeri adalah pariwisata yang berbasis syariah, wisata syariah sangat ngetrend untuk hari ini, apalagi melihat jumlah penduduk Indonesia menurut data badan pusat statistik ada sekitar 268.583.016 jiwa. ${ }^{11}$ Adapun menurut data badan pusat statistik Indonesia jumlah penduduk muslim di Indonesia sekitar 256,820,000 jiwa. ${ }^{12}$ Maka pariwisata yang berbasis syariah di Indonesia target utamanya adalah orang Islam karena melihat orang Islamlah yang paling banyak di Indonesia, dengan adanya segmentasi yang disediakan dalam pariwisata syariah. Memberikan pelayanan terhadap wisatawan muslim yang ingin melakukan perjalanan wisata sesuai dengan prinsip-prinsip Islam, sehingga wisatawan muslim merasa lebih nyaman dan aman dalam menikmati perjalanan wisata, serta dapat melaksanakan kewajibannya sebagai seorang muslim sesuai dengan ajaran Islam seperti wajib mengkonsumsi makanan dan minuman yang halal, melaksanakan sholat wajib dan adanya hotel syariah.

\section{Wisata dalam Perspektif Islam}

\footnotetext{
${ }^{10}$ Nouvandi Dkk, "Potensi Dan Prospek Wisata Syariah Dalam Meningkatkan Ekonomi Daerah 'Studi Kasus Kota Bandung,'” Jurnal Of Business And Enterpreurnership Volume. 1 Nomer. 2 (April 2019 ): 93.

${ }^{11}$ Kemendagri Zudan Arif Fakhrullah, “Data Kependudukan 2020 : Penduduk Indonesia Menurut Dirjen Dukcapil , Kenaikan Total Jumlah Penduduk Yaitu Sebesar 0,77 Persen Nasional" (Kompas.Com, November 2, 2020), Https://nasional.kompas.com/read/2020/08/12/15261351/data-kependudukan-2020penduduk-indonesia-268583016-jiwa.

12 “Berapa Jumlah Penduduk Muslim Indonesia Databoks," November 2, 2020, Https://databoks.katadata.co.id/datapublish/2019/09/24/berapa-jumlah-penduduk-muslim-indonesia.
} 
Al-qur'an berbicara tentang alam dan fenomenanya, paling sedikit ada tiga hal yang dapat dikemukakan menyangkut hal tersebut diantaranya. ${ }^{13}$ Al-Qur'an memerintahkan atau menganjurkan kepada manusia untuk memperhatikan dan mempelajari alam raya dalam rangka memperoleh manfaat dan kemudahankemudahan bagi kehidupannya, serta untuk mengantarkannya kepada kesadarannya akan keesaan dan maha kuasa Allah swt. Alam dan segala isinya beserta hukum-hukum yang mengaturnya, diciptakan, dimiliki, dan dibawa kekuasaan Allah swt serta diatur sangat teliti. Alam raya tidak dapat melepaskan diri dari ketetapan-ketetapan tersebut kecuali dikendaki oleh tuhan. Dari sini alam raya atau elemen-elemennya tidak boleh disembah, dipertuhankan atau dikultuskan, manusia dapat menarik kesimpulankesimpulan tentang adanya ketetapan yang bersifat umum dan mengikat bagi alam raya dan fenomenanya. Redaksi ayat-ayat kawniyah bersifat ringkas, teliti lagi padat, sehingga pemahaman atau penafsiran terhadap ayat-ayat tersebut dapat menjadi sangat bervariasi sesuai dengan tingkat kecerdasan dan pengetahuan masing-masing penafsir. ${ }^{14}$

Sementara dalam pandangan ulama dalam rangka membedakannya, menamai ayat pertama sebagai ayat kawniyah dan yang kedua sebagai ayat Qur'aniyah. Secara harfiyah, ayat berarti tanda dalam arti rambu rambu perjalanan menuju ridha Allah Swt atau bukti-bukti kekuasaan dan keesaan Allah Swt. ${ }^{15}$ Tanda tersebut tidak bisa difungsikan dengan baik sebagai tanda kecuali apabila didengar atau dipandang, baik dengan mata hati maupun dengan mata kepala sebagai salah satu panca indra. Karena itu dalam Alqur'an ditemukan sekian banyak perintah-perintah Allah yang berkaitan dengan pemungsian tanda-tanda tersebut. Khusus yang menyangkut pandangan, tidak kurang dari tujuh ayat yang mengaitkan secara perintah pandangan itu dengan perjalanan, seperti ayat, berjalanlah diatas bumi dan lihatlah. Bahkan al-saihun (wisatawan) yang melakukan perjalanan dalam rangka memperoleh ibrah (Pelajaran dan pengajaran). Kata al-saihun terambil dari kata siyahah yang secara populer diartikan wisata. Kata ini mengandung arti penyebaran karena itu dari kata tersebut dibentuk kata sahat yang berarti lapangan yang luas. ${ }^{16}$

Kata safara dalam al-qur'an mempunyai beragam makna antara lain membuka dan membersihkan debu. Menunjukkan warna seperti dalam surat al-muddastsir: (34). Melakukan perjalanan sebagaimana dalam surat al-nisa: (34). Bermakna kitab seperti yang diungkapkan dalam surah al-jumu'ah:(5). Adapun kata sara dalam al-qur'an bermakna Perintah ikhtiar (usaha) dan keinginan untuk melakukan perjalanan seperti pada surat yunus: (22). Bermakna sekelompok orang seperti pada surat yusuf: (19). Bermakna menundukkan sesuatu seperti menundukkan gunung sebagaimana yang diungkapkan pada surat al-takwir: (3). Kondisi secara naluriah (gharizah) atau yang diupayakan (muktasabiyah) yang ada pada diri seseorang sebagaimana diungkapkan

\footnotetext{
${ }^{13}$ Quraisy Shihab, Membumikan Al-Qur'an (Bandung : Mizan, 1999), 132.

${ }^{14}$ Quraisy Shihab, 133.

${ }^{15}$ Nurcholis Madjid, Islam Universal (Bandung : Pustaka Pelajar, 2007), 245.

${ }^{16}$ Al-Raghib Al-Asfahany, Mu'jam Al-Mufradat Fi Gharib Al-Qur'an (Bairut: Dar Al-Fikr, 2013), 253.
} 
pada surat thaha: (21). Melakukan perjalanan dimuka bumi dalam rangka mendidik kehendak dan memperluas jiwa mereka. ${ }^{17}$

Melihat ayat-ayat yang memakai kata sara dan derivasinya dalam al-qur'an hal ini karena menurut hemat penulis kata ini lebih dekat maknanya dengan kata pariwisata, dari 27 ayat yang menggunaknan sara, 14 ayat diantaranya menunjukkan anjuran dari Allah Swt untuk melakukan perjalanan baik itu disekitar tempat tinggal ataupun keluar daerah dan tempat-tempat yang jauh, uniknya, 7 ayat diungkapkan dalam bentuk perintah dan ayat 7 lainnya dalam bentuk istifham inkary, dan semuanya diiringi dengan perintah untuk melakukan nazhara yang bermakna memperhatikan. Dalam kehidupan ummat manusia didunia ini, Islam selalu menyerukan agar manusia dalam bepergian dan bergerak menghasilkan kebaikan dunia dan akhirat, hal ini diungkapkan dalam Alqur'an dengan menggunakan bentuk perintah (amr) Allah SWT menyerukan kepada ummat manusia agar melakukan perjalanan yang diringi dengan memperhatikan apa yang mereka lihat tersebut. Hal ini berarti manusia akan mendapatkan nilai plus pada rihlah jika diiringi dengan tadabbur, karena tadabbur akan mengingatkan posisi manusia sebagai hamba Allah SWT dimuka bumi, jadi tidak hanya kesenangan yang menjadi tujuan awal, tetapi, hasil dari perjalanannya juga mendapat pahala dari Allah SWT.

Ketika Allah menyebut "berjalanlah di muka bumi", itu artinya Allah mengingatkan kita kepada alam ini, sehingga ada wisata alam, banyak hal di alam ini yang dapat dijadikan objek wisata, karena Allah menciptakan alam ini dengan kekhasan yang berbeda-beda. Dalam pandangan Muhammad Jamaluddin Al-Qasimiy menguraikan dalam tafsirnya bahwa siyahah adalah perjalanan wisata, karena menurutnya, cukup banyak bukti dan indikator didalam ayat alqur'an, bahwa banyak didalam ayat Alqur, an tersebut memerintahkan agar mengorbankan sebagian dari masa hidupnya untuk melakukan wisata dan perjalanan agar ia dapat menemukan peninggalan-peninggalan lama, mengetahui berita ummat terdahulu, agar semua itu menjadi sumber pelajaran. ${ }^{18} \mathrm{Jadi}$, dalam ajaran Islam pun telah diterangkan secara jelas tentang diperbolehkanya pariwisata ke berbagai tempat diberbagai dunia dengan maksud dan tujuan tertentu yang sesuai dengan syariah ${ }^{19}$ misalnya wisata dengan tujuan untuk beribadah sepert haji dan umrah, untuk menambah wawasan dan pengetahuan agama seperti ke tempat yang menyimpan sejarah tentang Islam, untuk berdakwah dan menyiarkan agama Islam, pergi ke beberapa tempat untuk melihat berbagai peninggalan sebagai nasehat, pelajaran dan manfaat lainnya dan menikmati indahnya alam yang indah sebagai pendorong jiwa manusia untuk menguatkan keimanan terhadap keesaan Allah dan memotivasi menunaikan kewajiban hidup.

Syaikhul Islam Taimiyyah Rahmatullah berkata: adapun berkelana tanpa tujuan tertentu, maka hal ini bukanlah amalan umat ini, oleh karenanya, Imam ahmad rahmatullah berkata: berkelana (tanpa tujuan) sedikitpun bukan termasuk ajaran agama

${ }^{17}$ Muhammad Rasyid Ridha, Tafsir Al-Manar (Kairo: Maktabah Al-Mannar, 2007), 53.

18 Muhajirin, "Pariwisata Dalam Tinjauan Ekonomi Syariah," Jurnal Almaslahah Volume. 06 Nomer.01 (March 2018): 96.

${ }_{19}$ Al-Raghib Al-Asfahany, Mu'jam Al-Mufradat Fi Gharib Al-Qur'an, 220. 
Islam dan bukan amalan para nabi dan orang-orang shalih. Al-Hafidz Ibnu Katsir berkata :bukanlah maksud dari berkelana adalah seperti pemahaman sebagian orang yang ahli ibadah yang hanya sekedar berkelana dibumi dan menyendiri digunung, pada pasir dan goa. Berkelana semacam itu tidak disyariatkan kecuali di zaman fitnah dan kegongcangan agama. Syaikh Al-Albani juga berkata pada saat mengomentari hadits larangan safar sendirian, "Didalam hadits ini terdapat bantahan yang amat jelas tentang keluarnya sebagian sufi ke jalanan secara sendirian dengan tujuan berkelana dan penyucian jiwa bahkan setiap kerap kali mereka mati karena kelaparan dan kehausan sebagaimana diceritakan dalam hikayat-hikayat mereka dan sebaik-baik petunjuk adalah petunjuk nabi Muhammad. ${ }^{20}$ Melakukan perjalanan atau rihlah atau dengan istilah modernnya pariwisata tidak hanya sekedar memberikan peringatan dan mengingatkan jati diri manusia sebagai hamba Allah tetapi pariwisata juga punya keuntungan dibalik itu. Ada beberapa keuntungan yang didapat dengan menjalankan pariwisata yang sesuai dengan syari'at Islam yaitu dengan menambah khasanah pengetahuan dan rasa syukur kepada Allah swt akan ciptaannya.

Dalam kehidupan berbangsa dan bernegara di Indonesia segala aktivitas masyarakat Indonesia diatur oleh Undang-undang dasar Negara Indonesia apalagi dalam undang-undang pariwisata. Bunyi undang-undang nomor 10 tahun 2009 tentang kapariwisataan pasal 5 butir A ayat A menyebutkan "kepariwisataan diselenggarakan dengan prinsip menjunjung tinggi norma agama dan nilai budaya sebagai pengejawantahan dari konsep hidup dalam keseimbangan antara manusia dan Tuhan Yang Maha Esa. ${ }^{21}$ Hubungan antara manusia dan sesama manusia dan hubungan manusia dengan lingkungan " berdasarkan pasal ini maka kebijakan dalam penyelenggaraan dan pengembangan pariwisata di Indonesia harus didasarkan pada nilai-nilai agama dan adat istiadat setempat. ${ }^{22}$

Pertimbangan Undang-Undang Nomor 10 Tahun 2009 tentang Kepariwisataan adalah: bahwa keadaan alam, flora, dan fauna, sebagai karunia Tuhan Yang Maha Esa, serta peninggalan purbakala, peninggalan sejarah, seni, dan budaya yang dimiliki bangsa Indonesia merupakan sumber daya dan modal pembangunan kepariwisataan untuk peningkatan kemakmuran dan kesejahteraan rakyat sebagaimana terkandung dalam Pancasila dan Pembukaan Undang-Undang Dasar Negara Republik Indonesia Tahun 1945.

Selain itu, kepariwisataan telah berkembang menjadi suatu fenomena global, menjadi kebutuhan dasar, serta menjadi bagian dari hak asasi manusia yang harus dihormati dan dilindungi. Pemerintah dan Pemerintah Daerah, dunia usaha pariwisata, dan masyarakat berkewajiban untuk dapat menjamin agar berwisata sebagai hak setiap

${ }^{20}$ Quraisy Shihab, Tafsir Almisbah Pesan, Kesan Dan Keserasian Alqur'An (Jakarta : Lentera Hati, 2007), 34 .

${ }^{21}$ Laurensius Arliman, "Peran Investasi Dalam Pembangunan Ekonomi Bidang Pariwisata di propinsi Sumatera Barat," Jurnal Ilmu Hukum Volume. 20 Nomer.2 (Agustus 2018): 274.

22 “Undang-Undang Nomor 10 Tahun 2009 Pusat Data Hukum Online.Com," Desember 2020, Https://m.hukumonline.com/pusatdata/detail/29086/nnprt/1060/undangundang-nomer.10tahun2009.Diakses. 
orang dapat ditegakkan sehingga mendukung tercapainya peningkatan harkat dan martabat manusia, peningkatan kesejahteraan, serta persahabatan antarbangsa dalam rangka mewujudkan perdamaian dunia. ${ }^{23}$ Dalam menghadapi perubahan global dan penguatan hak pribadi masyarakat untuk menikmati waktu luang dengan berwisata, perlu dilakukan pembangunan kepariwisataan yang bertumpu pada keanekaragaman, keunikan, dan kekhasan bangsa dengan tetap menempatkan kebhinekaan sebagai suatu yang hakiki dalam bingkai Negara Kesatuan Republik Indonesia. Selain itu, pembangunan kepariwisataan harus tetap memperhatikan jumlah penduduk. Jumlah penduduk akan menjadi salah satu modal utama dalam pembangunan kepariwisataan pada masa sekarang dan yang akan datang karena memiliki fungsi ganda, di samping sebagai aset sumber daya manusia, juga berfungsi sebagai sumber potensi wisatawan nusantara.

Dengan demikian, pembangunan kepariwisataan dapat dijadikan sarana untuk menciptakan kesadaran akan identitas nasional dan kebersamaan dalam keragaman. Pembangunan kepariwisataan dikembangkan dengan pendekatan pertumbuhan dan pemerataan ekonomi untuk kesejahteraan rakyat dan pembangunan yang berorientasi pada pengembangan wilayah, bertumpu kepada masyarakat, dan bersifat memberdayakan masyarakat yang mencakup berbagai aspek, seperti sumber daya manusia, pemasaran, destinasi, ilmu pengetahuan dan teknologi, keterkaitan lintas sektor, kerja sama antarnegara, pemberdayaan usaha kecil, serta tanggung jawab dalam pemanfaatan sumber kekayaan alam dan budaya. Dalam pelaksanaannya, pembangunan kepariwisataan sebagaimana diatur dalam Undang-Undang Nomor 9 Tahun 1990 tentang Kepariwisataan masih menitikberatkan pada usaha pariwisata. ${ }^{24}$ Oleh karena itu, sebagai salah satu syarat untuk menciptakan iklim yang kondusif dalam pembangunan kepariwisataan yang bersifat menyeluruh dalam rangka menjawab tuntutan zaman akibat perubahan lingkungan strategis, baik eksternal maupun internal, perlu mengganti Undang-Undang Nomor 9 Tahun 1990 dengan undang- undang yang baru. Materi yang diatur dalam Undang-Undang ini meliputi, antara lain hak dan kewajiban masyarakat, wisatawan, pelaku usaha, Pemerintah dan Pemerintah Daerah, pembangunan kepariwisataan yang komprehensif dan berkelanjutan, koordinasi lintas sektor, pengaturan kawasan strategis, pemberdayaan usaha mikro, kecil, dan menengah di dalam dan di sekitar destinasi pariwisata, badan promosi pariwisata, asosiasi kepariwisataan, standarisasi usaha, dan kompetensi pekerja pariwisata, serta pemberdayaan pekerja pariwisata melalui pelatihan sumber daya manusia.

Indonesia sebagai Negara dengan penduduk mayoritas beragama Islam memiliki kekayaan tradisi dan adat istiadat yang tidak bisa dipisahkan dari agamanya. Tradisi dan budaya yang ada dimasyarakat saat ini adalah manifestasi dari agama dan kepercayaanya. Sehingga saat ini, tidak bisa lagi dipisahkan antara adat istiadat atau budaya dengan agama keduanya telah melebur dalam satu kesatuan yaitu tradisi

23 Muhajirin, "Pariwisata Dalam Tinjauan Ekonomi Syariah," Jurnal Almaslahah Volume. 06 Nomer.01 (March 2018): 77.

${ }^{24}$ Abdurrahman Misno, "Analisis Praktik Pariwisata Syariah Perspektif Hukum Ekonomi Syariah," Jurnal Ekonomi Dan Bisnis Islam Volume. 01 Nomer.04 (January 2019): 65. 
dimasyarakat Indonesia. Berangkat dari fenomena inilah maka objek wisata dalam bentuk budaya di Indonesia pada umumnya adalah bagian dari agama Islam yang telah menjadi kebanggaan masyarakat Indonesia. Sehingga apabila budaya tersebut akan dijadikan obyek wisata maka mau tidak mau harus mempertimbangkan agama masyarakatnya yaitu Islam. Sebagai agama mayoritas masyarakat Indonesia maka Islam menjadi kepercayaan dan bagian kehidupan masyarakat Indonesia, Negara yang memiliki populasi muslim terbesar diseluruh dunia pada saat ini diperkirakan bahwa jumlah ummat muslim mencapai 207 juta orang. ${ }^{25}$

Kekayaan tradisi, budaya, agama dan adat istiadat masyarakat muslim Indonesia inilah yang melatar belakangi munculnya wisata syariah oleh pemerintah republik Indonesia melalui kementerian pariwisata dan ekonomi kreatif atau (Kemenprekraf). Alasan utama dikembangkannya program ini adalah karena meningkatnya minat masyarakat lokal dan internasional dan layanan wisata berbasis syariah Islam. ${ }^{26}$ Kemenparekraf mencatat bahwa kunjungan wisata muslim ke Indonesia saat ini mencapai 1.270. 437 orang pertahun yang antara lain berasal dari Arab Saudi, Malaysia, dan Singapura. Seperti Negara-negara lain didunia, produk dan pelayanan wisata dengan nilai-nilai syariah ini diminati oleh wisatawan muslim yang populasinya mencapai 1.8 miliar atau $28 \%$ populasi dunia. ${ }^{27}$ Wisatawan muslim berkontribusi sekitar 126 miliar dollar Amerika pada tahun 2016 dan diperkirakan pada tahun 2020 mereka akan membelanjakan 192 miliar dollar Amerika untuk kebutuhan wisata mereka. Jumlah ini merupakan $13,24 \%$ dari pengeluaran wisatawan global dan akan terus meningkat pada tahun-tahun yang akan datang.

Pariwisata Syariah adalah Suatu kegiatan wisata yang didukung dengan berbagai fasilitas serta layanan yang sesuai dengan prinsip Syariah. ${ }^{28}$ Adapun yang dimaksud dengan prinsip syariah adalah prinsip hukum Islam terkait berbagai kegiatan pariwisata berdasarkan fatwa yang dikeluarkan oleh lembaga yang berwenang. Di Indonesia lembaga dimaksud adalah Dewan Syariah Nasional Majelis Ulama Indonesia (DSN-MUI)."Pariwisata syariah dapat didefinisikan sebagai berbagai kegiatan wisata yang didukung berbagai fasilitas dan layanan yang disediakan masyarakat, pengusaha, pemerintah yang memenuhi ketentuan syariah. Pariwisata syariah merupakan suatu permintaan wisata yang didasarkan pada gaya hidup wisatawan muslim selama liburan. Selain itu, pariwisata syariah merupakan pariwisata yang fleksibel, rasional, sederhana dan seimbang.Pariwisata ini bertujuan agar wisatawan termotivasi untuk mendapatkan kebahagiaan dan berkat dari Allah. ${ }^{29}$

25 "Sejarah Islam Di Indonesia Perkembangan Agama Islam Di nusantara," Desember 2020, Https://www.indonesia-investments.com/id/budaya/agama/islam/item248.

${ }^{26}$ Juhaya S Praja, Ekonomi Syariah, 67.

27 “140 Juta Wisman Muslim Diproyeksikan Kunjungi Indonesia Pada Tahun 2020,” Desember

2020, Https://www.antaranews.com/berita/1165355/140-juta-wisman-muslim-diproyeksikan-kunjungiindonesia-pada-2020.

${ }^{28}$ Nouvandi Dkk, “Potensi Dan Prospek Wisata Syariah Dalam Meningkatkan Ekonomi Daerah 'Studi Kasus Kota Bandung,'” 91.

${ }^{29}$ Ibnu Mandzur, Lisaan Al-Arab (Beirut: Dar Lisa Al-Arab, 2007), 119. 
Pariwisata syariah yang dijabarkan, terdapat empat aspek penting yang harus diperhatikan untuk menunjang suatu pariwisata syariah. ${ }^{30}$ Lokasi Penerapan sistem Islami di area pariwisata. Transportasi penerapan sistem, seperti pemisahan tempat duduk antara laki-laki dan wanita yang bukan mahram sehingga tetap berjalannya syariat Islam dan terjaganya kenyamanan wisatawan. Konsumsi Islam sangat memperhatikan segi kehalalan konsumsi ${ }^{31}$ dan Hotel seluruh proses kerja dan fasilitas yang disediakan berjalan sesuai dengan prinsip syariah.

Berdasarkan fatwa dewan syariah nasional nomer 108/DSN-MUI/X2016 tentang pedoman penyelenggaraan pariwisata berdasarkan prinsip syariah, ${ }^{32}$ pariwisata adalah berbagai macam kegiatan wisata dan didukung berbagai fasilitas serta layanan yang disediakan oleh masyarakat, pengusaha, pemerintah dan pemerintah derah. ${ }^{33}$ Pariwisata syariah adalah pariwisata yang sesuai dengan prinsip syariah, destinasi wisata syariah ialah kawasan geografis yang berada dalam satu atau lebih wilayah administratif yang didalamnya terdapat daya tarik wisata, fasilitas ibadah dan umum, fasilitas pariwisata, aksesbilitas, serta masyarakat yang saling terkait dan melengkapi terwujudnya kepariwisataan yang sesuai dengan prinsip syariah. ${ }^{34}$

\section{Pertimbangan Halal dan Tayyib pada Wisata Non Halal Di Madura}

Dapat disimpulkan bawah wisata syariah yaitu wisata yang ingin memberikan pelayanan dan fasilitas wisata kepada muslim yang juga dapat dinikmati oleh wisatawan non muslim. Ada tiga syarat dasar yang harus diterapkan untuk menjadikan wisata syariah yaitu ${ }^{35}$ Adanya fasilitas dan layanan ibadah yang memadai, tempat tinggal yang ramah terhadap wisata muslim (hotel syariah). Makanan dan minuman dengan jaminan halal melalui sertifikat badan tertentu yang mempunyai kewajiban menangani hal itu. Adanya fasilitas atau infrastruktur untuk ibadah, seperti adanya masjid atau musholla disekitar tempat wisata.

Adapun ketika wisata syariah tersebut, keluar dari pada nilai-nilai syariat Islam yang sudah difatwakan oleh MUI maka perlu elemen masyarakat sebagai orang Islam berhak memberikan teguran kepada pemilik wisata dengan pendekatan yang telah diajarkan oleh syariat Islam, disini penulis akan menjelaskan tata cara menegur permasalahan sosial yang sesuai dengan syariat Islam. Elemen-elemen ini seluruhnya hampir harus ada dalam wisata di Madura, sebagai pertimbangan bisnis yang halal serta tidak merusak budaya lokal masyarakat Madura.

\footnotetext{
${ }^{30}$ Nouvandi Dkk, "Potensi Dan Prospek Wisata Syariah Dalam Meningkatkan Ekonomi Daerah 'Studi Kasus Kota Bnadung,'” 67.

31 "Wikipedia Bahasa Indonesia, Ensiklopedia Bebas," Desember 2020, https://id.wikipedia.org/wiki/obyek_wisata.

32 Happy Marpaung, Pengetahuan Kepariwisataan (Bandung : Alfabeta, 2002), 55.

${ }^{33}$ Nanda Rahmi, "Kajian Ekonomi Pariwisata Syariah Kota Banda Aceh," Jurnal Samudera Ekonomi Dan Bisnis Volume. 8 Nomer.1 (January 2017): 578.

${ }^{34}$ Nurcholis Madjid, Islam Universal, 88.

${ }^{35}$ Nouvandi Dkk, "Potensi Dan Prospek Wisata Syariah Dalam Meningkatkan Ekonomi Daerah 'Studi Kasus Kota Bandung,'” 93.
} 
Masyarakat Madura yang begitu kental dengan nuansa Islami, akan mensoroti wisata yang dianggap merusak moral masyarakat terutama pemudanya. Seperti pertimbangan halal yang dilakukan oleh masyarakat Madura terhadap wisata yang dianggap tidak halal oleh masyarakat yaitu wisata kedai bukit bintang yang ada di daerah Pamekasan Madura. Wisata ini dianggap tidak halal oleh masyarakat dengan beberapa pertimbangan seperti penjelasan masyarakat bahwa wisata bukit Bintang Sangat meresahkan warga karena bukanya malam hari, dan lokasi berdekatan dengan pondok pesantren. Sudah dipanggil oleh pihak pesantren untuk tidak buka sampai larut malam. ${ }^{36}$ Dengan beberapa pertimbangan tersebut masyarakat melakukan beberapa tindakan untuk melakukan pengembalian citra Islami dalam wisata.

Setelah dilakukan kajian para pimpinan pondok pesantren yang berdekatan dengan lokasi wisata memohon untuk menutup wisata tersebut "Kedai Bukit Bintang" yang berlokasi di Dusun Beltok Desa Larangan Badung Palengngaan Pamekasan dengan pertimbangan lokasi berdekatan dengan pesantren, berpotensi menjadi tempat berkumpulnya laki-laki dan perempuan, tidak pernah bermusyawarah dengan pimpinan pondok pesantren, menimbulkan keresahan pada pesantren dan masyarakat, serta mencegah tumbuh suburnya tempat-tempat wisata baru yang bertentangan dengan norma etik pesantren yang merusak Pamekasan sebagai kota pendidikan dan Gerbang Salam. ${ }^{37}$ Beberapa tindakan dilakukan tidak lain untuk memberikan teguran kepada pemilik wisata, agar mempertimbangkan kehalalan dari wisata.

Islam memiliki tata cara menegur kesalahan seperti di dalam surah An-Nahl ayat 125, juz 16: "serulah (manusia) kepada jalan Tuhanmu dengan hikmah dan pengajaran yang baik, dan berdebatlah dengan mereka dengan cara yang baik. Sesungguhnya Tuhanmu, Dialah yang lebih mengetahui siapa yang sesat dari jalan-Nya dan Dialah yang mengetahui siapa yang mendapat petunjuk."Dalam penafsiran al misbah karya M. Qurays Sihab penafsiran ayat di atas yaitu : untuk mengajak umat manusia ke jalan yang di tunjukkan Allah SWT, yaitu jalan orang yang berjalan musafir, berjuang, menuntut ilmu, dan kebaikankebaikan yang telah Allah perintahkan kepada nabi Muhammad SAW, dengan cara memerintah cara pengajaran yang baik mengetahui jalan kebenaran, sesuatu yang apabila mendatangkan hikmah, atau apabila digunakan akan mendatangkan kemudahan, keselamatan serta tidak terjadi yang namanya kemudharatan atau kesulitan yang besar. ${ }^{38}$

Ayat diatas juga telah dilakukan oleh para tokoh agama dan masyarakat seperti Faisol bahwa teguran pertama dilakukan langsung kepada pemilik wisata. Namun pemilik tidak mau menutup wisata tersebut. Dari inilah teguran selanjutnya dilakukan sampai pada teguran terakhir dilakukan. ${ }^{39}$ seperti halnya dalam surat pernyataan yang menjelaskan tentang rapat untuk membuat surat pernyataan dihadiri oleh beberapa pimpinan pondok pesantren di pamekasan antara lain; RKH. Moh. Rofi'e Baidhowi (PP

${ }^{36}$ Supryadi, Wawancara Online, Desember 2020.

37 Tokoh dan Pimpinan Pondok Pesantren, "Surat Pernyataan Sikap Para Tokoh Dan Pimpinan Pondok Pesantren" (Pondok Pesantren Darul Ulum Banyuanyar Pamekasan, September 2, 2020).

${ }^{38}$ Quraisy Shihab, Tafsir Almisbah Pesan, Kesan Dan Keserasian Alqur'An, 93-94.

${ }^{39}$ Faisol, Wawancara Warga Sekitar Wisata di Plakpak Pagentenan Pamekasan, Desember 2020. 
Darul Ulum Banyuanyar), RKH Hasbullah Arifin (PP Darul Ulum Banyuanyar), RKH Ahmad Faisol Abdul Hamid (PP. Mambaul Ulum bata-bata), RKH M. Faiq Abdul Ghofur (PP. al mujtama' Plakpak), RKH Minnatullah (PP. Jabalul Baqir wal Maliki), RKH Abdul Majid (PP. Maktuba al Majidiyah Palduding), RKH Mohammad Alwi (PP. Pake Panaan Palengngaan), RKH Abdul Hannan Tibyan (PP. Puncak Darussalam), RKH Moh, Bakir Hasan (PP. Palpettok Pagentenan), RKH M. Khoirul Wafa (PP. Miftahul Ulum Panyeppen), dan RKH Ali Murtadlo (PP. Bukit Anbar Pagentenan). ${ }^{40}$

Proses penutupan sangat alot karena lambatnya pemerintah setempat untuk menutup wisata tersebut, sehingga pihak satpol PP mengambil alih untuk menutup wisata tersebut dan secara resmi telah ditutup. ${ }^{41}$ Massa membakar tempat wisata yang dianggap menjadi sarang maksiat, wisata ini telah sering dilaporkan oleh warga jadi sarang maksiat, dan pemilik wisata sudah dimediasi dengan tokoh masyarakat, perwakilan warga, aparat desa dan keamanan dari TNI dan Polri. Namun pemilik menolak untuk menutup wisata, padahal izin usaha tempat wisata tersebut tidak sesuai dengan yang diajukan. ${ }^{42}$

Masyarakat sangat antusias dengan adanya wisata bukit bintang terutama para pemuda, perekonomian masyarakat mendapat peluang sektor pedagangan kecil Usaha Mikro Kecil Menengah, karena banyaknya pemuda yang berkholwat, dan telah ditegur beberapa kali supaya ditutup karena berisi kemaksiatan, cara penutupan diamuk oleh warga dan kemungkinan besar tidak akan dibuka kembali karena banyaknya tokoh agama besar yang melarang hal tersebut, dan juga kultur Madura yang fanatik terhadap guru sehingga pembukaan kembali merupakan kemustahilan. ${ }^{43}$

Kami sebagai masyarakat merasa tidak nyaman dengan wisata yang dibuat oleh salah satu oknum, yang dalam proses pembuatannya tidak melalui kajian sosial bersama-sama dengan kami, serta secara hukum juga tidak sah kurang manfaatnya dari awal pembuatannya sudah kurang benar karena tidak melibatkan musyawarah dan ijin dari warga. Proses pembubaran pertama disurati, kedua kalinya diperingatkan secara langsung oleh warga, ketiga kalinya diingatkan melalui kasun setempat, setelah beberapa teguran tidak diindahkan kemudian warga sekitar langsung mendatangi lokasi membongkar dan membakar lokasi tersebut, seperti meja-meja dan beberapa anyaman bambu untuk tempat selfi. Tempat hiburan ini tidak akan dibuka kembali, kecuali ada musyawarah dan kesepakatan bersama antara warga dan para pemodal. ${ }^{44}$

Ada beberapa faktor terjadinya perusakan wisata oleh warga diantaranya untuk menjaga kearifan lokal sebab tempat wisata berdekatan dengan pondok pesantren, potensi campur aduk laki-laki dan perempuan yang tidak sesuai dengan kultur pesantren sebagai pengembangan pendidikan. Proses penutupan dengan pernyataan sikap dari sejumlah tokoh pondok pesantren yang berdekatan dengan lokasi wisata atau

40 Tokoh dan Pimpinan Pondok Pesantren, "Surat Pernyataan Sikap Para Tokoh Dan Pimpinan Pondok Pesantren."

${ }^{41}$ Supryadi, Wawancara Online.

${ }^{42}$ Kontributor Pamekasan, Taufoqurrahman, "Massa Bakar Tempat Wisata Di Pamekasan Karena Diduga Jadi Sarang Maksiat," Oktober 2020, KOMPAS.com.

${ }^{43}$ Firoh, Wawancara pada Para Millenial, Desember 2020.

${ }^{44}$ Faisol, Wawancara Warga Sekitar Wisata di Plakpak Pagentenan Pamekasan. 
di area perbukitan dan pernyataan sikap yang ditandatangani pada 8 September 2020 ditujukan kepada kapolsek palengngaan dilengkapi dengan tembusan kepada Camat Palengngaan. Koramil Palengngaan, serta Kepala Desa Larangan Badung. Dimana dalam surat pernyataan sikap tersebut sudah disertakan beragam pertimbangan. Proses penutupan dengan cukup lama dengan beberapa proses dan jalan terakhir merusak dengan cara membakar wisata tersebut. ${ }^{45}$

Selanjutnya aksi perusakan dipimpin oleh Muhammad Hasanurrahman kasi Kabupaten Pamekasan yang berlokasi di Desa Larangan Badung Kabupaten Pamekasan pertimbangan peraturan daerah kabupaten Pamekasan Nomor 2 tahun 2019 perubahan atas peraturan Nomor 3 Tahun 2015 tentang penyelenggaraan hiburan dan rekreasi. Peraturan pemerintah Kabupaten Pamekasan nomor 3 tahun 2019 tentang ketertiban umum dan ketentraman masyarakat. Serta peraturan daerah Kabupaten Pamekasan Nomor 18 Tahun 2019 tentang penyelenggaran penanaman modal. Tindakan ini sudah disetujui dari berbagai pihak, sehingga penutupan berjalan tanpa ada penegoran dari pihak kepolisian. ${ }^{46}$

Dalam menyeru kepada agama Allah di lakukan 3 tahap dan 3 tingkatan, yang mana masing-masing di sesuaikan dengan kondisi objek, 3 tingkatan seruan yaitu : Pertama, Serulah yaitu dengan agrumen yang pasti berguna bagi akidah-akidah keyakinan dan merupakan tingkatan seruan yang paling tinggi. Metode ini di gunakan kepada mereka yang sudah mampu mempersiapkan diri ke arah yang lebih sempurna. Kedua, Mengajak yaitu seruan dengan cara-cara yang sesuai dengan situasi dan kondisi objek yang bisa di terima oleh manusia dan dapat mengantar kepada kebaikan, tetap memegang teguh agama Allah, bebas dari budaya perselisihan. Ketiga, Mujadalah yaitu dengan cara menggunakan bukti-bukti yang mematahkan argumentasi dan menjadikan tidak bertahan, akan tetapi ketika mendapat perlawanan yang berat terkadang harus menggunakan argumen-argumen yang keras dan kokoh yang bisa mengalahkan orangorang yang diserunya atau yang di nasehati.

Dalam hadist Nabi juga dijelaskan Dari Abu Sa'id Al-Khudri radhiyallahu anhu ia berkata: Aku mendengar Rasulullah saw "Barangsiapa dari kalian melihat kemungkaran, ubahlah dengan tangannya. Jika tidak bisa, ubahlah dengan lisannya. Jika tidak bisa, ingkarilah dengan hatinya, dan itu merupakan selemah-lemahnya iman".([HR. Muslim, no. 49). Hadits Abu sa'id ini menjelaskan mengenai tingkatan dalam mengingkari kemungkaran, hadist ini juga menunjukkan bahwasanya barang siapa yang mampu untuk merubah kemungkaran dengan tangannya, maka wajib dia menempuh cara tersebut. Namun perlu diperhatikan bahwa hal ini hanya boleh dilakukan oleh orang yang memiliki kemampuan kekuasaan terhadap orang yang ada dibawahnya dan bukan sembarang orang yang boleh merubah dengan tangannya.

Beberapa pandangan tokoh Islam mengenai tafsir amar makruf nahi mungkar diantaranya, Norcholis Madjid menyampaikan bahwa orang lebih tertarik bernahi

\footnotetext{
${ }^{45}$ Hj Fawaz, Wawancara Warga Karang Penang Sampang Madura, Desember 2020.

${ }^{46}$ Muhammad Hasanurrahman, “Nomor BA. Penutupan/300/906.PPNS/432.305/2020 Pada Hari Senin Tanggal 05 Oktober 2020" (Pamekasan, Oktober 2020).
} 
munkar dari pada ber-amar makruf, karena nahi mungkar lebih banyak mengandalkan semangat, sedangkan amar ma'ruf lebih mengandalkan keilmuan, bernahi mungkar tanpa didahului amar ma'ruf akan menghasilkan gerakan kekerasan, gerakan mudah menyalahkan. Idealnya menurut cak Norcholis Madjid dalam ber-amar ma'ruf dan bernahi mungkar, mengorbankan tidak bisa koleksi, semangat haruslah dilandasi dengan keilmuan, dan itulah dakwah dari pada bil khayr. ${ }^{47}$

Selanjutnya, Sayyid Quthb mengartikan amar ma'ruf nahi munkar sebagai jalan yang harus ada jama'ah menyuruh kepada kebajikan dan melarang kepada yang munkar. ${ }^{48}$ Amar ma'ruf nahi munkar merupakan suatu perbuatan yang mengajak kepada kebajikan dan melarang dari perbuatan buruk. Alhabib Rizieq Syihab pemimpin front pembela Islam menjelaskan bahwa gerakan menegakkan amar ma'ruf nahi munkar adalah suatu keharusan. Bahkan ini adalah kewajiban dunia Islam secara keseluruhan. Menurut Habib Rizieq sebagai negara muslim terbesar didunia, gerakan nasional anti kemaksiatan dicanangkan sebagai bukti bahwa kami tidak akan pernah menyerah pada kemaksiatan. ${ }^{49}$

\section{KESIMPULAN}

Nilai halal dalam bisnis harus menjadi patokan utama bagi masyarakat muslim agar keberkahan dari apa yang diusahakan mendapatkannya. Begitu pula dalam kajian ini dapat disimpulkan bahwa pertimbangan halal oleh masyarakat menjadi tugas bersama bagi semua masyarakat Madura untuk tetap menjaga nilai-nilai Islam dalam setiap aspek kehidupan. Sehingga keberadaan wisata Bukit Bintang yang ada di Pamekasan Madura menjadi salah satu wisata yang dirusak oleh masyarakat Madura dengan pertimbangan bahwa wisata tersebut tidak halal dalam prosesnya. Adapun salah satu faktor yaitu; wisata menjadi tempat maksiat karena menjadi tempat berkhalwat antara laki-laki dan perempuan; dibuka sampai malam hari; berdekatan dengan Pondok Pesantren, merusak nilai lokal Madura yang bernuansa Islami. Sedangkan beberapa tindakan yang dilakukan oleh masyarakat Madura dalam memberikan teguran yaitu pertama, mendatangi pemiliki wisata agar mengubah operasi wisata. Kedua, memberikan teguran melalui kepala daerah setempat. Ketiga, pernyataan sikap oleh sejumlah tokoh agama. Keempat, masyarakat membakar tempat wisata dengan pertimbangan bahwa wisata merupakan wisata non halal yang akan merusak moral remaja.

Perusakan yang dilakukan oleh masyarakat Madura dilakukan setelah keluarnya berita acara penutupan Nomor BA. Penutupan/300/906.PPNS/432.305/2020 pada hari Senin tanggal 05 Oktober 2020 yang diketuai oleh Muhammad Hasanurrahman Jabatan Kasi.Penyidikan Kabupaten Pamekasan berdasarkan perintah

${ }^{47}$ Kaursar Azhari Noer, and Dkk, Titik- Temu (Jakarta : NCMS Norcholis Madjid Society, 2014), 39.

48 Aidah Fatharturrohman, "Amar Ma'Ruf Nahi Munkar Dalam Pespektif Al-Qur,An (Study Komparatif Dalam Penafsiran Sayyid Qutlh Dan Al-Sya'rawi," Skripsi Program Sarjana Ilmu Al-Qur'an Dan Tafsir Universitas Islam Negeri Syarif Hidayatullah Jakarta, n.d., 42.

49 "Melihat Model Amar Ma'ruf Nahi Munkar Versi FPI," Desember 2020, https://ibtimes.id/melihat-model-amar-maruf-nahi-munkar-versi-fpi. 
surat keputusan penutupan Nomor: SPT. Penutupan/300/904.PPNS/432.305/2020 dengan pertimbangan peraturan daerah kabupaten Pamekasan Nomor 2 tahun 2019 perubahan atas peraturan Nomor 3 Tahun 2015 tentang penyelenggaraan hiburan dan rekreasi. Peraturan Pemerintah Kabupaten Pamekasan nomor 3 tahun 2019 tentang ketertiban umum dan ketentraman masyarakat. Serta peraturan daerah Kabupaten Pamekasan Nomor 18 Tahun 2019 tentang penyelenggaraan penanaman modal. Selain pertimbangan di atas, perusakan ini juga dilandasi oleh surat keputusan atau oleh beberapa Pimpinan Pondok Pesantren di Pamekasan antara lain; RKH. Moh. Rofi'e Baidhowi (PP Darul Ulum Banyuanyar), RKH Hasbullah Arifin (PP Darul Ulum Banyuanyar), RKH Ahmad Faisol Abdul Hamid (PP. Mambaul Ulum Bata-Bata), RKH M. Faiq Abdul Ghofur (PP. al Mujtama' Plakpak), RKH Minnatullah (PP. Jabalul Baqir wal Maliki), RKH Abdul Majid (PP. Maktuba al Majidiyah Palduding), RKH Mohammad Alwi (PP. Pake Panaan Palengngaan), RKH Abdul Hannan Tibyan (PP. Puncak Darussalam), RKH Moh, Bakir Hasan (PP. Palpettok Pagentenan), RKH M. Khoirul Wafa (PP. Miftahul Ulum Panyeppen), dan RKH Ali Murtadlo (PP. Bukit Anbar Pagentenan) pada tanggal 2 September 2020.

\section{REFERENSI}

"140 Juta Wisman Muslim Diproyeksikan Kunjungi Indonesia Pada Tahun 2020," Desemner 2020. Https://www.antaranews.com/berita/1165355/140-jutawisman-muslim-diproyeksikan-kunjungi-indonesia-pada-2020.

Abduh. Wawancara Warga Plakpak Pamekasan, Desember 2020.

Abdurrahman Misno. "Analisis Praktik Pariwisata Syariah Perspektif Hukum Ekonomi Syariah." Jurnal Ekonomi Dan Bisnis Islam Volume. 01 Nomer.04 (January 2019).

Aidah Fatharturrohman. "Amar Ma'Ruf Nahi Munkar Dalam Pespektif Al-Qur,An (Study Komparatif Dalam Penafsiran Sayyid Qutlh Dan Al-Sya'rawi." Skripsi Program Sarjana Ilmu Al-Qur'an Dan Tafsir Auaniversitas Islam Negeri Syarif Hidayatullah Jakarta, n.d.

Al-Raghib Al-Asfahany. Mu'jam Al-Mufradat Fi Gharib Al-Qur'an. Bairut: Dar Al-Fikr, 2013.

“Berapa Jumlah Penduduk Muslim Indonesia Databoks," November 2, 2020. Https://databoks.katadata.co.id/datapublish/2019/09/24/berapa-jumlahpenduduk-muslim-indonesia.

Erwandi Tarmizi. Harta Haram Muamalat Kontemporer. 21st ed. P.T Berkat Mulia Insani, 2019.

Faisol. Wawancara Warga Sekitar Wisata di Plakpak Pagentenan Pamekasan, Desember 2020. 
Firoh. Wawancara pada Para Millenial, Desember 2020.

Happy Marpaung. Pengetahuan Kapariwisataan. Bandung : Alfabeta, 2002.

Hervina, Hervina. "Trend Halal Food Di Kalimantan Timur." FENOMENA 9, no. 2 (2017): 175-186.

Hj Fawaz. Wawancara Warga Karang Penang Sampang Madura, Desember 2020.

Ibnu Mandzur. Lisaan Al-Arab. Beirut : Dar Lisa Al-Arab, 2007.

Jaih Mubarok, and Hasanudin. Fikih Mu'malah Maliyah Akad Syirkah Dan Mudharabah. Ketiga. SImbiosa Rekatama Media, 2019.

Juhaya S Praja. Ekonomi Syariah. Bandung : Pustaka Setia, 2015.

Kaursar Azhari Noer, and Dkk. Titik- Temu. Jakarta : NCMS Norcholis Madjid Society, 2014.

Kemendagri Zudan Arif Fakhrullah. “Data Kependudukan 2020 : Penduduk Indonesia Menurut Dirjen Dukcapil , Kenaikan Total Jumlah Penduduk Yaitu Sebesar 0,77 Persen Nasional." Kompas.Com, November 2, 2020. Https://nasional.kompas.com/read/2020/08/12/15261351/data-kependudukan2020-penduduk-indonesia-268583016-jiwa.

"Kewajiban Mengubah Kemungkaran Dari Abu Sa'id Al-Khudri Radhiyallahu Anhu," desember 2020. https://muslim.or.id/158-kewajiban-mengubah-kemungkaran.

Kontributor Pamekasan, Taufoqurrahman. "Massa Bakar Tempat Wisata Di Pamekasan Karena Diduga Jadi Sarang Maksiat," Oktober 2020. KOMPAS.com.

Laurensius Arliman. "Peran Investasi Dalam Pembangunan Ekonomi Bidang Pariwisatadipropensi Sumatera Barat." Jurnal Ilmu Hukum Volume. 20 Nomer.2 (Agustus 2018).

"Melihat Model Amar Ma'ruf Nahi Munkar Versi FPI," Desember 2020. https://ibtimes.id/melihat-model-amar-maruf-nahi-munkar-versi-fpi.

Muhajirin. "Pariwisata Dalam Tinjauan Ekonomi Syariah." Jurnal Almaslahah Volume. 06 Nomer.01 (March 2018).

Muhajirin. "Pariwisata Dalam Tinjauan Ekonomi Syariah." Jurnal Almaslahah Volume. 06 Nomer.01 (March 2018).

Muhammad Hasanurrahman. "Nomor BA. Penutupan/300/906.PPNS/432.305/2020 Pada Hari Senin Tanggal 05 Oktober 2020.” Pamekasan, Oktober 2020.

Muhammad Rasyid Ridha. Tafsir Al-Manar. Kairo : Maktabah Al-Mannar, 2007. 
Nanda Rahmi. “Kajian Ekonomi Pariwisata Syariah Kota Banda Aceh.” Jurnal Samudera Ekonomi Dan Bisnis Volume. 8 Nomer.1 (January 2017).

Nouvandi Dkk. "Potensi Dan Prospek Wisata Syariah Dalam Meningkatkan Ekonomi Daerah 'Studi Kasus Kota Bnadung.'” Jurnal Of Business And Enterpreurnership Volume. 1 Nomer. 2 (April 2019).

Nurcholis Madjid. Islam Universal. Bandung : Pustaka Pelajar, 2007.

Maggalatung, A.S.; Aji, A.M.; Yunus, N.R. How The Law Works, Jakarta: Jurisprudence Institute, 2014.

Aji, A.M.; Yunus, N.R. Basic Theory of Law and Justice, Jakarta: Jurisprudence Institute, 2018.

Yunus, N.R.; Anggraeni, RR Dewi.; Rezki, Annissa. "The Application of Legal Policy Theory and its relationship with Rechtsidee Theory to realize Welfare State," 'Adalah, Volume 3, No. 1 (2019)

"Pengertian Wisata Secara Umum Aneka Tempat Wisata," Desember 2020. Https://anekatempatwisata.com/pengertian-wisata-secara-umum/.

Quraisy Shihab. Membumikan Al-Qur'an. Bandung: Mizan, 1999.

Quraisy Shihab. Tafsir Almisbah Pesan, Kesan Dan Keserasian Alqur'An. Jakarta : Lentera Hati, 2007.

Rahmi Syahriza. "Pariwisata Berbasis Syariah Telaah Makna Kata Sara Dan Derivasinya Dalam Alqu'an" Volume. 1 Nomer 2 (July 2015).

Said, Muhammad M., and Kaviyarasu Elangkovan. "Halal Label and the Ethics of Business: An Analytical View from Producers." Australian Journal of Basic and Applied Sciences 7, no. 6 (2013): 613-621.

“Sejarah Islam Diindonesia Perkembangan Agama Islam Dinusantara," Desember 2020. Https://www.indonesia-investments.com/id/budaya/agama/islam/item248.

Supryadi. Wawancara Online, Desember 2020.

Tokoh dan Pimpinan Pondok Pesantren. "Surat Pernyataan Sikap Para Tokoh Dan Pimpinan Pondok Pesantren." Pondok Pesantren Darul Ulum Banyuanyar Pamekasan, September 2, 2020.

“Undang-Undang Nomer 10 Tahun 2009 Pusat Data Hukum Online.Com," Desember 2020. 
Https://m.hukumonline.com/pusatdata/detail/29086/nnprt/1060/undangundang -nomer.10tahun-2009.Diakses.

"Wikipedia Bahasa Indonesia, Ensiklopedia Bebas," Desember 2020. https://id.wikipedia.org/wiki/obyek_wisata.

Yusuf, Asnidar Hanim, S. Abdul Shukor, and U. Ahmad Bustamam. "Halal Certification vs Business Growth of Food Industry in Malaysia." Journal of Economics, Business and Management 4, no. 3 (2016): 247-251.

Zulfa, Indana. "Pengaruh Persepsi Label Halal Terhadap Minat Beli Dan Keputusan Pembelian Pada Produk Wardah Cosmetic: Studi Pada Mahasiswi Fakultas Ekonomi UIN Maulana Malik Ibrahim Malang Angkatan 2014." PhD Thesis, Universitas Islam Negeri Maulana Malik Ibrahim, 2017. 